\title{
Solunum Sistemi Konusunun İlköğretimde Dramatizasyon Tekniği ile Öğretiminin Öğrenci Başarısına Etkisi
}

\section{The Effect of Teaching the Respiratory System with Dramatization Technique on Students' Achievement in Primary School}

\author{
Gamze DİKMENLİ VARDAR* \\ Mahmut SELVI'** \\ Ayşe Nesibe KÖKLÜKAYA***
}

\begin{abstract}
Öz: Bu çalışmanın amacı, ilköğretim altıncı sınıf Fen ve Teknoloji dersi "Vücudumuzda Sistemler" ünitesinde yer alan "Solunum Sistemi" konusunun öğretiminde dramatizasyon tekniğinin kullanılmasının öğrencilerin akademik başarısı üzerindeki etkisini incelemektir. Araştırma ön test-son test kontrol gruplu yarı deneysel desene göre yapılmıştır. Araştırmanın örneklemi 2012-2013 eğitim-öğretim yılı bahar döneminde İstanbul ili Arnavutköy ilçesinde bir devlet ilköğretim okulunun 6. sınıfında öğrenim gören 56 öğrenciden oluşmaktadır. Araştırmada veri toplama aracı olarak Temelli, Arlı, Biber ve Kurt (2011) tarafından geliştirilen ve KR 21 değeri 0.81 olan başarı testi kullanılmıştır. Araştırmanın sonuçlarına göre deney grubu ile kontrol grubu ögrencileri arasında başarı ve cinsiyet bakımından anlamlı bir farklılık olmadığı görülmüştür. Ancak deney grubu öğrencilerinin başarı son test puanları arasında kız öğrenciler lehine anlamlı bir farklılık olduğu görülmüştür. Aynı zamanda deney ve kontrol grubu öğrencilerinin başarı testinden aldıkları uygulama öncesi ve sonrası puanları arasında anlamlı bir fark olduğu belirlenmiştir.
\end{abstract}

Anahtar sözcükler: Dramatizasyon Tekniği, Fen ve Teknoloji, Solunum Sistemi, Akademik başarı

Abstract: The aim of this study was to examine the effects of teaching with dramatization technique on sixth grade students" academic achievement concerning the "Respiratory System" subject in the "Systems in Our Body" unit in "Science and Technology" lessons of $6^{\text {th }}$ grade in primary school. Therefore this research is of the pre-test/post-test quasi-experimental design. The research sample consisted of 56 students from 6th grade of a public primary school in Arnavutköy during the spring term of the academic year 2012-2013. An Achievement test with a reliability coefficient of 0.81 , developed by Temelli, Arl1, Biber and Kurt (2011) was employed as a data collection tool. At the result of statistical analysis, no positive and meaningful results were found between the experimental and control groups. However, the final test achievement scores of the experimental group showed that there was a significant difference on behalf of the female students. Also it was determined that there was a significant difference between the pre-test and post-test scores in the experimental group and also in the control group.

Keywords: Dramatization Technique, Respiratory System, Science and Technology, Achievement

\footnotetext{
* Fen Bilimleri Öğretmeni, Bolluca Türk Tekstil Vakfi Ortaokulu, İstanbul. gamze.dikmenli@gmail.com

** Prof. Dr., Gazi Üniversitesi, Gazi Eğitim Fakültesi, Fen Bilgisi Öğretmenliği ABD, Ankara. mselvi@gazi.edu.tr

*** Dr., Gazi Üniversitesi, Gazi Eğitim Fakültesi, Fen Bilgisi Öğretmenliği ABD, Ankara. nkoklukaya@gazi.edu.tr $\mathrm{Bu}$ çalışma Gamze Dikmenli Vardar'ın yüksek lisans tezinden üretilmiştir.
} 


\section{Giriş}

Zamanın sürekli akması bununla birlikte bir değişim sürecini oluşturur. Yeni teknolojiler, buluşlar hep bu değişimin ve daha iyisini gerçekleştirmenin eseridir. Bu duruma ise gözlerimizi kapatmamız mümkün değildir. Gelişmeleri geriden takip etmemek için bize düşen görev öncelikle değişmelere uyum sağlamaktır. Onun ardından ise çağın gerektirdiği teknolojiyi yakalamak, anlamak ve arkasından da yeni teknolojiler üretmek gerekmektedir. Dünyada meydana gelen hızlı değişime toplumun ayak uydurabilmesinde en önemli etken eğitimdir. Çünkü eğitim, insanların toplum yaşayışında yerlerini almaları için gerekli bilgi, beceri ve anlayışları elde etmelerine, kişiliklerini geliştirmelerine okul içinde veya dışında doğrudan veya dolaylı yardım eder (TDK 2004). 2000'li yıllara kadar benimsenmiş olan geleneksel eğitim sisteminde öğrenci merkezde yer almıyor, bu nedenle eğitim sürecinde etkin olamıyordu. Bireylere belli kalıplar öğretiliyor, ezberletiliyor ve yeni durumlara bu şekilde uyum göstermesi isteniyordu. $\mathrm{Bu}$ da yaratıcılığın, özgürce düşünmenin ve hareket etmenin, araştırmanın, irdeleyip yorum yapmanın önüne geçiyordu. Günümüzde eğitimden beklenen, bireylerin ezbere dayalı bilgilerle donatılmaları değil, edindikleri bilgileri kendi yaşamlarına yararlı olacak şekilde uygulayabilmelerinin sağlanması, kendi davranışlarının sorumluluğunu üstlenebilen, diğer insanlara karşı da sorumlu olduğunu hisseden bireyler yetiştirilmesidir (Önder 1999). Sözü edilen özelliklere sahip fen okuryazarı bireyler yetişitirilmesi açısından öğrencilerin aktif olduğu öğretim yöntem ve tekniklerinin kullanılması gerekliliği MEB (2013) tarafından ifade edilmiştir.

Geleneksel eğitim sistemi daha çok bilişsel alanda gelişimi gerçekleştirirken, çağdaş eğitim anlayışı sayesinde öğrencilerin çok yönlü gelişimi desteklenmiş; bilişsel alanın yanında duyuşsal, psikomotor ve sosyal alanlarda da gelişim göstermeleri sağlanmıştır. Çağdaş eğitim sistemiyle birlikte artık merkezde birey bulunduğu için kullanılan öğretim yöntem ve tekniklerinde de değişim meydana gelmiştir. Uygulanan bu tekniklerden bir tanesi de dramatizasyon tekniğidir. Dramanın derslerde kullanılmasına ilişkin bilgilerde ilk olarak 1911'li yıllarda bir köy öğretmeni olan Harriet Finlay-Johnson'ın adı geçmektedir. Bu uygulamalar “öyleymiş gibi yарта оуипи" (make believe play) olarak isimlendirilmiştir (San 2002). Türkiye'deki okullarda dramatik etkinliklerin ve sahne oyunlarının derslerde gerçek anlamda hayat bulması Cumhuriyet devrinden itibaren görülmesine rağmen meşrutiyetten sonra daha çok anlam kazanmaya başlamıştır (Çoruh 1950). Günümüzde oyuna koyma, oyunlaştırma veya bir durumu gerçekte olduğundan daha heyecan verici ya da kötü göstermek olarak açılanabilecek olan dramatizasyon, daha çok yazılı bir metne dayalı olarak bir konunun, öykünün, masalın ya da bir durumun canlandırılması olarak tanımlanmaktadır (Hesapçıoğlu 1997; Dirim 1998; Çakır 2012). Rol oynama ise belirlenmiş kurallar çerçevesinde özgür bir şekilde oyun kurma, bu oyunları geliştirme çalışmalarının yapıldığı öğretim tekniğidir. Yaratıcılık boyutunda sürece dahil etmesi bakımından dramatizasyon tekniğinden ayrılmaktadır (San 2001). Dramatizasyonda bir oyun metninin aynısının ya da bir öykünün, masalın hiçbir biçimde akışını değiştirmeden canlandırılması söz konusudur. Bu canlandırmalarda öykünün ya da metnin seçimi son derece önemlidir. Sözgelimi seçilen öykünün çocuklara yönelik olması veya katılımcıların düzeyine uygun olması, sahne ve giysilerin öyküde anlatılan gerçek havayı yansıtıcı, karakterlerin ise ilginç olmasına özen gösterilmelidir (Adıgüzel 2010).

Dramatizasyon etkinliklerinde sınıfta bulunan öğrenci duygularını paylaşmayı öğrenir. Aynı zamanda kendi duygularını gerçekçi bir şekilde ortaya koyar (Linnell 1982). Dramatizasyon uygulamalarında öğrencilere sorunun çözümü ile birlikte onların katılan diğer kişilerin doğasını anlama, insan davranışlarını değerlendirme, insan ilişkilerindeki sorunları kavrama firsatı sunulur. Bu yöntemde öğrenciler bir tepki veya ceza ile karşılaşma tehlikesi olmadan kendilerini 
bir başkasının yerine koyar, onun gibi düşünür, duyar ve davranır (Kavcar 2006).

Dramatizasyon tekniğinin başarılı bir şekilde yürütülmesi, uygulamadan önce öğretmen tarafından planlanmasına ve plana uygun olarak hareket edilmesine bağlıdır. Uygulama öncesinde genel amacın ve konunun belirlenmesi, uygulama sırasında kullanılabilecek araçgereçlerin, kaynakların ve materyallerin hazırlanması, uygulamanın yapılacağı gruba nasıl oynanacağı konusunda bilgi verilmesi, uygulama sırasında öğrencilerin farklı roller almasının sağlanması, uygulama sırasında grubun gözlemlenmesi, gruba yardımcı olunması, uygulamanın sonunda tartışma yapılarak uygulamanın değerlendirilmesi gerekmektedir (Paykoç 1987; Dirim 1998; Ekinözü 2003).

Dramatizasyon tekniği eğitim öğretim ortamlarında çeşitli alanlarda kullanılmaktadır. Alanyazında yapılan çalışmalar incelendiğinde, dramatizasyon yönteminin Hayat Bilgisi dersinde kullanılmasının öğrencilerin sosyal duygusal uyumlarına ve akademik başarılarına olumlu yönde etkilediği (Bilek 2009) yine dramatizasyon tekniğinin öğrencilerin motivasyonunu yüksek tutacağı, öğrencilerin bilimi anlamlandırması kadar yazma becerilerine de katkıda bulunacağını Ediger (2001) tarafından belirtilmiştir. Aynı şekilde Siddall (1999) dramatizasyon tekniğinin öğrencilerin sözlü ve sözsüz kendilerini ifade etmelerinde etkili bir yöntem olduğunu belirtmiş̧ir. Biegler (1998) hikayelerin anlaşılmasında dramatizasyon tekniğini kullanmış ve dramatizasyon tekniğiyle ders işleyen öğrencilerin konuyu daha iyi kavradıklarını belirtmiştir. Şengül ve Örnek Tükenmez (2009) dramatizasyon yönteminin, öğrencilerin hem matematik başarısı hem de tutum düzeyi üzerinde etkili olduğunu belirtmişlerdir. San (1990) dramatizasyon etkinlikleri ile kişilerin demokratik bir ortamda çeşitli ve değişik ilişkiler kurarak tecrübe kazanabileceğini ifade etmiştir. Dorion (2009), soyut kavramların öğretiminde pandomim ve rol oynama yöntemlerinin kullanılabileceğini ifade ederek, bu etkinliklerin öğrencilerin gözlem yeteneklerini geliştireceğini, soyut kavramları zorlanmadan, somutlaştırma yaparak anlamlandırabileceğini ifade etmiştir. Kahyaoğlu, Yavuzer ve Aydede (2010) ilköğretim 5. sınıf Fen Bilgisi dersi “Isı ve Isının Maddedeki Yolculuğu” ünitesinin drama etkinlikleri ile öğretiminin geleneksel öğretim yöntemine göre daha etkili olduğunu belirtmiştir.

Günümüz eğitim yaklaşımının amacına hizmet eden dramatizasyon tekniğindeki çalışmalarla çocuğun öğrenme sürecinde etkin durumda olduğu ayrıca kendi yaptığıyla öğrenirken bir yandan da duyu organlarını harekete geçirerek olay ya da durumları yaşadığı bilinmektedir. Bu nedenle dramatizasyon tekniğinin öğrencileri özgürce düşünmeye sevk etme, çevrelerine karşı duyarlılıklarını arttırma, empati kurma gibi özellikleri ile uygulamalara dayalı olan Fen ve Teknoloji dersinin amacına uygun olduğu görülmektedir. Fen ve Teknoloji dersinde pek çok konuda dramatizasyon tekniğinin akademik başarıya etkisi ortaya konulmuş ancak "Solunum Sistemi" konusunda bu tekniğin etkililiği daha önce test edilmemiştir (Yazkan 2000; Oğur \& Bağcı-Kılıç 2005). Bu bağlamda diğer çalışmalardan ayrılarak literatüre katk1 sağlayacağı düşünülen bu araştırma ile ilköğretim altıncı sınıf Fen ve Teknoloji dersi "Vücudumuzda Sistemler" ünitesinde yer alan "Solunum Sistemi" konusunun öğretiminde, dramatizasyon tekniğinin kullanılmasının öğrencilerin akademik başarılarındaki etkisini belirlemek amaçlanmıştır. Bununla birlikte araştırmanın problem cümlesi "İlköğretim altıncı sinıf Fen ve Teknoloji dersi 'Vücudumuzda Sistemler' ünitesinde yer alan 'Solunum Sistemi' konusunun ögretiminde dramatizasyon tekniğinin kullanılmasının ögrencilerin akademik başarısı üzerindeki etkisi var mıdır?" şeklinde ifade edilmiştir. Araştırmanın alt problemleri ise,

1. Dramatizasyon tekniğinin uygulandığı deney grubu ile öğretmen merkezli geleneksel yöntemin uygulandığı kontrol grubunun ön test başarı puan ortalamaları arasında istatistiksel olarak anlamlı bir fark var midır? 
2. Dramatizasyon tekniğinin uygulandığı deney grubunun ön test ve son test başarı puanları arasında anlamlı bir fark var midir?

3. Öğretmen merkezli geleneksel yöntemin uygulandığı kontrol grubunun ön test ve son test başarı puanları arasında anlamlı bir fark var mıdır?

4. Deney ve kontrol gruplarının başarı son test puanları arasında istatistiksel olarak anlamlı bir fark var midir?

5. Kontrol grubu öğrencilerinin başarı son test puanları arasında cinsiyet açısından istatistiksel olarak anlamlı bir fark var midir?

6. Deney grubu öğrencilerinin başarı son test puanları arasında cinsiyet açısından istatistiksel olarak anlamlı bir fark var midır?

Çalışmanın hipotezleri ise şu şekilde belirtilmiştir:

Null Hipotezi 1: H01: Yaratıcı drama yönteminin uygulandığı deney ve öğretmen merkezli geleneksel yöntemin uygulandığı kontrol gruplarının ön test başarı puan ortalamaları arasında istatistiksel olarak anlamlı bir fark yoktur $(\mu 1-\mu 2=0)$.

Null Hipotezi 2: H02: Yaratıcı drama yönteminin uygulandığı deney grubunun ön test ve son test başarı puanları arasında anlamlı bir fark yoktur $(\mu 1-\mu 2=0)$.

Null Hipotezi 3: H03: Öğretmen merkezli geleneksel yöntemin uygulandığ1 kontrol grubunun ön test ve son test başarı puanları arasında anlamlı bir fark yoktur $(\mu 1-\mu 2=0)$.

Null Hipotezi 4: H04: Deney ve kontrol gruplarının başarı son test puanları arasında istatistiksel olarak anlamlı bir fark yoktur $(\mu 1-\mu 2=0)$.

Null Hipotezi 5: H05: Kontrol grubu öğrencilerinin başarı son test puanları arasında cinsiyet açısından istatistiksel olarak anlamlı bir fark yoktur $(\mu 1-\mu 2=0)$.

Null Hipotezi 6: H06: Deney grubu öğrencilerinin başarı son test puanları arasında cinsiyet açısından istatistiksel olarak anlamlı bir fark yoktur $(\mu 1-\mu 2=0)$.

\section{Yöntem}

Bu araştırmada ilköğretim altıncı sınıf Fen ve Teknoloji dersi "Vücudumuzda Sistemler" ünitesinde yer alan "Solunum Sistemi" konusunun öğretiminde dramatizasyon tekniğinin kullanılmasının öğrencilerin akademik başarısı üzerindeki etkisini incelemek amacıyla, ön testson test kontrol gruplu yarı deneysel model kullanılmıştır. Ön test - son test kontrol gruplu modelde, yansız atama ile oluşturulmuş iki grup bulunur. Bunlardan biri deney, öteki kontrol grubu olarak kullanılır. Her iki grupta da deney öncesi ve deney sonrası ölçmeler yapılır (McMillan \& Schumacher 2001; Christensen 2004; Karasar 2005). Araştırma, İstanbul ilinin Arnavutköy ilçesindeki bir devlet okulunda öğrenim gören altı tane 6. sınıf arasından ikisinin seçilmesiyle gerçekleştirilmiştir. Araştırma örnekleminde yer alacak iki 6. sınıf da, bu altı 6 . sınıf arasından rasgele seçilmiştir. Hazır sınıflardan rasgele bir şekilde deney ve kontrol gruplarının seçilmesinden dolayı araştırma yarı deneysel modeldir. Deney grubunda dramatizasyon tekniği, kontrol grubunda ise öğretmen merkezli geleneksel öğretim uygulanmıştır.

\section{Örneklem}

Örneklem grubunu 2012-2013 eğitim ve öğretim y1lının bahar döneminde İstanbul ili Arnavutköy ilçesindeki bir devlet ilköğretim okulunda öğrenim gören 56 altıncı sınıf öğrencisi oluşturmaktadır. Örneklem grununun 26'sı kız, 30’u erkek öğrencilerden oluşmaktadır.

\section{Uygulama süreci}

Uygulama sürecinde deney ve kontrol gruplarında dersler araştırmacı tarafından işlenmiştir. 
Kontrol grubu olarak belirlenen 6-A sınıfında "Solunum Sistemi" konusu öğretmen merkezli geleneksel yöntemle 4 hafta süreyle işlenmiştir. Deney grubu olarak belirlenen 6-E sinıfında ise "Solunum Sistemi" konusu dramatizasyon tekniği ile 4 hafta süreyle işlenmiştir. Kontrol grubu olarak atanan 6-A sınıfında derse başlamadan önce öğretmen, derse getirdiği konuyla ilgili görsel materyalleri öğrencilere göstererek onların ilgilerini çekmeyi amaçlamıştır. Daha sonra konu ders kitabı ile sunulmuş, kitapta geçen sorular öğrenciler tarafından cevaplandırılmıştır. Konu kitaptan işlendikten sonra öğretmen, soru cevap tekniğiyle öğrencilerin okuduklarını pekiştirmelerine yardımcı olmuştur. Daha sonra dersin başında getirdiği görsel materyalleri konuyla ilişkilendirmiştir. Deney grubu olarak atanan 6-E sınıfinda ise ders planları öğretmen tarafından hazırlanmıştır. Daha önce dramatizasyon tekniğiyle hiç ders işlememiş olan 6-E sınıfı öğrencilerine kısaca dersi nasıl işleyecekleri hakkında uygulama sürecinden önce bilgi verilmiştir. $\mathrm{Bu}$ bilgilendirmenin içeriğinde bir metnin okunacăg 1 , metin içinde geçen karakterlerin daha sonra canlandırılacağı, materyal hazırlayacakları ve son olarak yaptıklarıyla ilgili değerlendirmeye alınacakları bulunmaktadır. Deney grubunda derse başlamadan önce sınıf ortamı etkinliklere uygun hale getirilmiştir. Öğrencilerin kendilerini rahat hissetmeleri için bazı gündelik sorular sorulmuştur. Daha sonra önceden planlanmış metin, öğrencilere bir ya da iki kere okunmuş ve kendilerini metinde geçen karakterlerin yerine koymaları, karşılaştıkları koşulları da hayal etmeleri istenmiştir. Sonra gönüllü öğrenciler seçilerek karakterlerin başlarından geçen olayları canlandırmaları istenmiştir. Öğrencilere canlandırma esnasında istedikleri materyali kullanabilecekleri ve ortamı istedikleri gibi değerlendirebilecekleri söylenmiştir. Oyun oynandıktan sonra öğrenciler önceden hazırlanmış planda bulunan değerlendirme sorularıyla değerlendirmeye alınmıştır.

\section{Veri Toplama Aracı}

Araştırmada veri toplama aracı olarak Temelli, Arlı, Biber ve Kurt'un (2011) geliştirdikleri "Solunum Sistemi" konulu akademik başarı testi kullanılmıştır. 25 maddeden oluşan testin KR 20 değeri Temelli, Arlı, Biber ve Kurt (2011) tarafından 0.81 olarak hesaplanmıştır.

\section{Verilerin Analizi}

Araştırmada ölçme araçlarından elde edilen verilerin çözümlenmesi SPSS 11 (Statistical Package for the Social Sciences) paket programı ile gerçekleştirilmiştir. Analiz yapabilmek için hangi istatistiksel analiz yöntemlerinin kullanılacağının belirlenmesinde öncelikle verilerin normal dağılım gösterip göstermediğine bakılmış ve bu sebeple verilere Normallik testi uygulanmıştır. Test sonunda verilerin normal dağılım göstermediği belirlenmiş ve non-parametrik testlerin kullanılmasına karar verilmiştir. Dramatizasyon tekniğinin uygulandığı deney ve öğretmen merkezli geleneksel yöntemin uygulandığı kontrol gruplarının ön test başarı puan ortalamaları arasında; dramatizasyon tekniğinin uygulandığı deney ve öğretmen merkezli geleneksel yöntemin uygulandığı kontrol gruplarının son test başarı puan ortalamaları arasında ve deney ve kontrol grubu öğrencilerinin başarı son test puanları arasında cinsiyet açısından istatistiksel olarak anlamlı bir fark olup olmadığının belirlenmesinde Mann-Whitney U testi kullanılmıştır. Dramatizasyon tekniğinin uygulandığ 1 deney grubunun ön test ve son test başarı puanları arasında ve öğretmen merkezli geleneksel yöntemin uygulandığı kontrol grubunun ön test ve son test başarı puanları arasında anlamlı bir fark olup olmadığının belirlenmesinde ise Wilcoxon İşaretli Sıralar Testi kullanılmıştır.

\section{Bulgular}

İlköğretim altıncı sınıf Fen ve Teknoloji dersi “Vücudumuzda Sistemler" ünitesinde yer alan "Solunum Sistemi” konusunun öğretiminde dramatizasyon tekniğinin kullanılmasının öğrencile- 
rin akademik başarısı üzerindeki etkisinin incelendiği bu çalışmada yer alan alt problemler sırasında elde edilen bulgular tablolar halinde sunulmuştur. İlk olarak araştırmada, deney ve kontrol gruplarında 28'er öğrenci yer aldığından dolayı verilerin normal dağılım gösterip göstermediğine bakılmıştır. Bu sebeple verilere Normallik Testi uygulanmıştır. Elde edilen sonuçlara Tablo 1'de yer verilmiştir.

Tablo 1. Kolmogorov-Smirnov Testi Sonuçları

\begin{tabular}{llc}
\hline & Başarı ön test & Başarı son test \\
\hline Kolmogorov- Smirnov (Sig) &, 003 &, 018 \\
\hline
\end{tabular}

Tablo 1'de verilen sonuçlara göre $\mathrm{p}<, 05$ olduğu için verilerin normal dağgllım göstermediği belirlenmiştir (Büyüköztürk 2007). Bu sebeple non-parametrik testlerin kullanılmasına karar verilmiştir.

\section{Birinci Alt Probleme İlişkin Bulgular;}

Dramatizasyon tekniğinin uygulandığ deney ve öğretmen merkezli geleneksel yöntemin uygulandığı kontrol gruplarının ön test başarı puan ortalamaları arasında istatistiksel olarak anlamlı bir fark var mıdır? alt problemi için, öğrencilerin ön testten aldıkları puanların analizinde Mann-Whitney U Testi kullanılmıştır. Elde edilen bulgular Tablo 2'de belirtilmiştir.

Tablo 2. Deney Ve Kontrol Grubundaki Öğrencilerin Solunum Sistemi Ön Testten Aldıkları Puanların Mann-Whitney U Testi ile Karşılaştırılması

\begin{tabular}{llllll}
\hline Grup & N & Sira Ortalamas1 & Sira Toplami & U & p \\
\hline Deney & 28 & 31,79 & 890,00 & 300 &, 130 \\
Kontrol & 28 & 25,21 & 706,00 & & \\
\hline
\end{tabular}

Tablo 2'deki analiz sonuçlarına göre deney ve kontrol grubundaki öğrencilerin solunum sistemi başarı ön testinden aldıkları puanların ortalamaları arasında istatistiksel olarak anlamlı bir farklılık ( $\mathrm{U}=300, \mathrm{p}>.05)$ bulunmamıştır. Bu sonuca dayanarak, uygulama başlamadan önce deney ve kontrol gruplarının başarı puanları açısından birbirine denk gruplar olduğu söylenebilir. "Dramatizasyon tekniğinin uygulandı̆̆ deney ve ögretmen merkezli geleneksel yöntemin uygulandiğ kontrol gruplarının ön test başarı puan ortalamaları arasında istatistiksel olarak anlamlı bir fark yoktur" hipotezi kabul edilmiştir.

\section{İkinci Alt Probleme İlişkin Bulgular;}

Dramatizasyon tekniğinin uygulandığı deney grubunun ön test ve son test başarı puanları arasında anlamlı bir fark var mıdır? alt problemi için, Wilcoxon İşaretli Sıralar Testi kullanılmıştır. Deney grubu öğrencilerinin uygulama öncesi ve sonrası başarı puanlarının anlamlı bir farklılık gösterip göstermediğine ilişkin Wilcoxon İşaretli Sıralar Testi sonuçları Tablo 3'te verilmiştir.

Tablo 3. Deney Grubu Öğrencilerinin Uygulama Öncesi ve Sonrası Başarı Testi Puanlarının Wilcoxon İşaretli Sıralar Testi Sonuçları

\begin{tabular}{llllll}
\hline Son test-Ön test & $\mathrm{N}$ & Sira Ortalamas1 & Sira Toplamı & $\mathrm{z}$ & $\mathrm{p}$ \\
\hline Negatif Sira & 7 & 10,57 & 74,00 & 2,18 &, 029
\end{tabular}




$\begin{array}{llll}\text { Pozitif Sira } & 17 & 13,29 & 226,00 \\ \text { Eşit } & 4 & & \end{array}$

Tablo 3'te verilen analiz sonuçları, araştırmaya katılan deney grubu öğrencilerinin başarı testinden aldıkları uygulama öncesi ve sonrası puanları arasında anlamlı bir fark olduğunu göstermektedir $(\mathrm{z}=2,18, \mathrm{p}<, 05)$. Fark puanlarının sira ortalaması ve toplamları dikkate alındığında, gözlenen bu farkın pozitif sıralar, yani son test puanı lehine olduğu görülmektedir. Bu sonuçlara göre, dramatizasyon tekniğinin öğrencilerin başarılarını geliştirmede önemli bir etkisinin olduğu söylenebilir. Böylece "Dramatizasyon tekniğinin uygulandı̆̆ deney grubunun ön test ve son test başarı puanları arasında anlamlı bir fark yoktur" hipotezi reddedilmiştir.

\section{Üçüncü Alt Probleme İlişkin Bulgular;}

Öğretmen merkezli geleneksel yöntemin uygulandığı kontrol grubunun ön test ve son test başarı puanları arasında anlamlı bir fark var mıdır? alt problemi için, Wilcoxon İşaretli Sıralar Testi kullanılmıştır. Kontrol grubu öğrencilerinin uygulama öncesi ve sonrası başarı puanlarının anlamlı bir farklılık gösterip göstermediğine ilişkin Wilcoxon İşaretli Sıralar Testi sonuçları Tablo 4'te verilmiştir.

Tablo 4. Kontrol Grubu Öğrencilerinin Uygulama Öncesi ve Sonrası Başarı Testi Puanlarının Wilcoxon İşaretli Sıralar Testi Sonuçları

\begin{tabular}{llllll}
\hline $\begin{array}{l}\text { Son test-Ön } \\
\text { test }\end{array}$ & $\mathrm{N}$ & Sira Ortalaması & Sira Toplamı & $\mathrm{z}$ & $\mathrm{P}$ \\
\hline Negatif Sira & 5 & 8,80 & 44,00 & 2,69 &, 007 \\
Pozitif Sıra & 17 & 12,29 & 209,00 & & \\
Eşit & 6 & & & & \\
\hline
\end{tabular}

Tablo 4'de verilen analiz sonuçlarına göre, araştırmaya katılan kontrol grubu öğrencilerinin başarı testinden aldıkları uygulama öncesi ve sonrası puanları arasında anlamlı bir fark olduğunu göstermektedir $(\mathrm{z}=2,69, \mathrm{p}<, 05)$. Fark puanlarının sıra ortalaması ve toplamları dikkate alındığında, gözlenen bu farkın pozitif sıralar, yani son test puanı lehine olduğu görülmektedir. $\mathrm{Bu}$ sonuçlara göre, öğretmen merkezli geleneksel yöntemin de öğrencilerin başarılarını geliştirmede önemli bir etkisinin olduğu söylenebilir. Böylece "Öğretmen merkezli geleneksel yöntemin uygulandığ kontrol grubunun ön test ve son test başart puanları arasında anlamlı bir fark yoktur" hipotezi reddedilmiştir.

\section{Dördüncü Alt Probleme İlişkin Bulgular;}

Dramatizasyon tekniğinin uygulandığı deney ve öğretmen merkezli geleneksel yöntemin uygulandığ 1 kontrol gruplarının son test başarı puan ortalamaları arasında istatistiksel olarak anlamlı bir fark var mıdır? alt problemi için, öğrencilerin son testten aldıkları puanların analizinde Mann-Whitney U Testi kullanılmıştır. Elde edilen bulgular Tablo 5'te verilmiştir. 
Tablo 5. Deney ve Kontrol Grubundaki Öğrencilerin Solunum Sistemi Son Testten Aldıkları Puanların Mann-Whitney U Testi İle Karşılaştırılması

\begin{tabular}{cccccc}
\hline Grup & $\mathrm{n}$ & Sira Ortalamas1 & Sira Toplamı & $\mathrm{U}$ & $\mathrm{p}$ \\
\hline Deney & 28 & 31,68 & 887,00 & 303,00 &, 143 \\
Kontrol & 28 & 25,32 & 709,00 & & \\
\hline
\end{tabular}

Tablo 5'deki analiz sonuçlarına göre deney ve kontrol grubundaki öğrencilerin başarı son testinden aldıkları puanların ortalamaları arasında istatistiksel olarak anlamlı bir farklılık $(\mathrm{U}=303, \mathrm{p}>, 05)$ bulunmamıştır. Böylece "Deney ve kontrol gruplarının başarı son test puanları arasinda istatistiksel olarak anlaml bir fark yoktur" hipotezi kabul edilmiştir.

\section{Beşinci Alt Probleme İlişkin Bulgular;}

Kontrol grubu öğrencilerinin başarı son test puanları arasında cinsiyet açısından istatistiksel olarak anlamlı bir fark var mıdır? alt problemi için, Mann-Whitney U Testi kullanılmıştır. Elde edilen bulgular Tablo 6' da verilmiştir.

Tablo 6. Kontrol Grubu Öğrencilerinin Son Test Puanlarının Cinsiyete Göre U Testi Sonuçları

\begin{tabular}{llllll}
\hline Grup & $\mathrm{n}$ & Sira Ortalamasi & Sira Toplami & $\mathrm{U}$ & $\mathrm{p}$ \\
\hline K1Z & 14 & 15,61 & 218,50 & 82,50 &, 48 \\
Erkek & 14 & 13,39 & 187,50 & & \\
\hline
\end{tabular}

Tablo 6'daki analiz sonuçlarına göre, kontrol grubu öğrencilerinin başarı son test puanları arasında cinsiyete göre istatistiksel olarak anlamlı bir farklılık bulunmadığı belirlenmiştir $(\mathrm{U}=82,50, \mathrm{p}>, 05)$. Böylece "kontrol grubu ögrencilerinin başarı son test puanları arasinda cinsiyet açısından istatistiksel olarak anlamlı bir fark yoktur" hipotezi kabul edilmiştir.

\section{Altıncı Alt Probleme İlişkin Bulgular;}

Deney grubu öğrencilerinin başarı son test puanları arasında cinsiyet açısından istatistiksel olarak anlamlı bir fark var mıdır? alt problemi için, Mann-Whitney U Testi kullanılmıştır. Elde edilen bulgular Tablo 6 ve Tablo 7'de verilmiştir.

Tablo 7. Deney Grubu Öğrencilerinin Son Test Puanlarının Cinsiyete Göre Mann-Whitney U Testi Sonuçları

\begin{tabular}{llllll}
\hline Grup & $\mathrm{n}$ & Sira Ortalamas1 & Sira Toplamı & $\mathrm{U}$ & $\mathrm{p}$ \\
\hline Kiz & 12 & 18,42 & 221,00 & 49,00 &, 029 \\
Erkek & 16 & 11,56 & 185,00 & & \\
\hline
\end{tabular}

Tablo 7'deki analiz sonuçlarına göre, deney grubu öğrencilerinin başarı son test puanları arasında kız öğrenciler lehine anlamlı bir farklılık olduğu görülmektedir $(\mathrm{U}=49, \mathrm{p}<, 05)$. "Deney grubu ögrencilerinin başarı son test puanları arasında cinsiyet açısından istatistiksel olarak anlamlı bir fark yoktur" hipotezi reddedilmiştir.

\section{Tartışma Sonuç ve Öneriler}

İlköğretim altıncı sınıf Fen ve Teknoloji dersi "Vücudumuzda Sistemler" ünitesinde yer alan 
"Solunum Sistemi" konusunun öğretiminde, dramatizasyon tekniğinin kullanılmasının öğrencilerin akademik başarılarındaki etkisinin belirlenmesinin amaçlandığ bu çalışmada elde edilen sonuçlar şu şekildedir.

İlk olarak birinci alt problem için, deney ve kontrol grubundaki öğrencilerin başarı ön testinden aldıkları puanların ortalamaları arasında istatistiksel olarak anlamlı bir farklılık olmadığ 1 sonucuna ulaşılmıştır. Yani uygulama yapılmadan önce kontrol ve deney grupları başarı puanları açısından birbirine denk kabul edilebilir.

İkinci alt problem olarak, araştırmaya katılan deney grubu öğrencilerinin başarı testinden aldıkları uygulama öncesi ve sonrası puanları arasında anlamlı bir fark olduğu tespit edilmiştir. Sonuçlar arasındaki farklılık son test puanları lehinedir. Araştırmanın bu sonucuna benzer pek çok araştırmaya alanyazında rastlanmaktadır (Ünüvar 2007; Debre 2008; Çam et al. 2009; Dorion 2009; Kahyaoğlu et al. 2010; Toy 2015). Dramatizasyon tekniğiyle öğrencinin bilgiye ulaşma ve onu kullanmada istekli hale geldiği Koç (2009) tarafından belirtilmiştir. Dramatizasyon tekniği ile akademik başarının artmasına paralel olarak San (1990) dramatizasyon ile öğretilen bilgilerin ezbere dayalı, kuramsal bilgiler olmadığını, hayatla bağlantılar kuran öznel ve nesnel ilişkiler içinde yapılanan bilgiler olduğunu belirtmiştir. Yine aynı şekilde Bilek (2009), araştırmasıyla dramatizasyon yönteminin Hayat Bilgisi dersinde kullanılmasının öğrencilerin sosyal, duygusal uyumlarını ve akademik başarılarını olumlu yönde etkilediğini ortaya koymuştur. Güllü’nün (2009) çalışmasında dramatizasyon tekniği ağırlıklı yöntemin uygulandığı deney grubunda, geleneksel yöntemin uygulandığ gruba göre yabancı dil öğrenme başarısının daha yüksek olduğu tespit edilmiştir. Biegler (1998) ise dramatizasyon tekniğiyle ders işleyen öğrencilerin konuyu daha iyi kavradıkları sonucuna ulaşılmıştır. Şengül ve Örnek Tükenmez (2009), farklı olarak çalışmalarında dramatizasyon tekniğini matematik ders başarısı açısından incelemişlerdir ve dramatizasyon tekniğinin, öğrencilerin matematik başarısını arttırmada etkili bir yöntem olduğu sonucuna ulaşmışlardır. Yazkan (2000) ise dramatizasyonun, anlamayı ve hatırlamayı kolaylaştırdığını, dinlediğini anlama becerisinin kazandırılmasında etkili bir yöntem olduğunu ifade etmiştir. Dramatizasyon tekniğinin akademik başarıya olumlu etkilerinin olduğu sonucuna ulaşan bu çalışmaların yanı sıra Yağmur (2010) ise, dramatizasyon tekniğinin akademik başarıya olumlu veya olumsuz katkısının olmadığını belirtmiştir. Çoğunlukla dramatizasyon tekniğinin akademik başarıya olumlu etkilerinin olduğu çalışmalarla bu çalışma paralellik göstermektedir.

Üçüncü alt problem olarak, araştırmaya katılan kontrol grubu öğrencilerinin başarı testinden aldıkları uygulama öncesi ve sonrası puanları arasında anlamlı bir fark olduğu sonucuna ulaşılmıştır. Sonuçlar arasındaki farklılık son test puanları lehinedir. Her öğrenme yönteminde olduğu gibi öğretmen merkezli geleneksel yöntemin de işlem basamakları vardır. Her öğrenme basamağında önce ve yeni öğrenilenler arasında yatay ve dikey ilişkiler kurulur. Böylece öğrencilerin anlamlı öğrenmesi sağlanır (Kaptan \& Korkmaz 1999). Öğrenme sürecinin gerçekleştiği bir ortamda böyle bir sonuç olması normal olarak olarak değerlendirilebilir. Benzer şekilde Karacil'in (2009) yaratıcı drama yönteminin öğrencilerin akademik başarılarına etkilerini incelediği çalışmasında paralel sonuçlara rastlanmıştır. Karacil (2009) yöntemi ne olursa olsun önemli olan unsurun öğrencilerin konuları anlamlandırabilmesi ve bunu değerlendirmeye yansıtması olduğunun altını çizmiştir.

Dördüncü alt problem olarak, deney ve kontrol grubundaki öğrencilerin başarı son testinden aldıkları puanların ortalamaları arasında istatistiksel olarak anlamlı bir farklılık olmadığı sonucuna ulaşılmıştır. Deney grubunun kontrol grubundan daha başarılı bulunamaması çeşitli sebeplere bağlanabilir. Bunlardan biri, dramatizasyon tekniği ile işlenen derslerde gerçekleştirilen 
etkinliklerin öğrencilerin test çözme becerisine bir katk1 sağlamaması olabilir. Yağmur (2010) yaratıcı drama ile ilgili yaptığı çalışmasında yaratıcı drama yönteminin öğrencilerin test çözme becerilerini ve başarılarını olumlu ya da olumsuz yönde etkilemediği sonucuna ulaşmıştır. $\mathrm{Bu}$ çalışmada da deney grubundaki öğrencilere çalışmanın başında ve sonunda uygulanan çoktan seçmeli başarı testini tamamlayıcı olarak öğrencilerin dramatizasyon tekniği uygulamalarında edindiği tecrübeleri tam olarak yansıtabilen ölçme değerlendirme aracı kullanılması başarılı bir sonuç gösterebilirdi. Ayrıca sınıf mevcudu dramatizasyon tekniğinin etkin kullanımını etkileyebilmektedir. Bertiz'in (2005) de belirttiği üzere sınıflardaki öğrenci sayıları önemli bir sorundur. Kalabalık sinıflarda öğrenme sürecinde çeşitli sorunlar yaşanmaktadır. $\mathrm{Bu}$ tür sinıflarda öğrencilerin kontrolü zorlaşabilmekte ve öğrencinin bireysel ihtiyaçları çoğunlukla ikinci planda kalabilmektedir. Koç'a (2009) göre, bir grup öğrencinin, diğerlerinin karşısında bir olayı, duyguyu, kavramı ya da konuyu sözlü ya da sözsüz olarak canlandırmasına dayanan dramatizasyonun, sınıftaki öğrencilerin büyük bir kısmının pasif durumda bıraktığını ifade etmiştir. Gösteriyi gerçekleştiren öğrencilerin dışında kalan büyük çoğunluk için kendi yaşantıları yoluyla öğrenmeden söz edilemeyeceğini belirtmiştir. Çünkü izleyici konumundaki öğrenciler tüm duyu organlarını kullanmazlar ve izlediklerini beyinlerinde anlamlandırmaya çalışarak öğrenmelerini oluştururlar. Bu sebeple dramatizasyon tekniğinin akademik başarıya büyük oranda olumlu etki oluşturamayacağı söylenebilir.

Son olarak kontrol grubu öğrencilerinin başarı son test puanları arasında cinsiyete göre istatistiksel olarak anlamlı bir farklılık yokken; deney grubu öğrencilerinin başarı son test puanları arasında kız öğrencilerinin lehine bir fark olduğu görülmüştür. 11-12 yaşlarındaki bu çocuklar gelişim dönemleri bakımından soyut işlemler dönemine adım atmaktadır. (Yalçın \& Karakaş 2008). Soyut işlemler döneminde kız çocukları erkek çocuklara göre daha çabuk el becerileri kazanırlar. Aynı şekilde, Becker ve Hedges (1984) de araştırmalarında kızların genellikle sözel etkinliklerde erkeklerden daha yüksek puanlar aldıklarını ifade etmiştir. Dramatizasyon tekniği uygulamalarımızda söz ve el becerileri gerektiren basamaklara yer verilmiş olmasından dolayı deney grubunda kız öğrenciler lehine bir farklılık meydana gelmiş olabilir. Alan yazın incelendiğinde bu çalışmadan farklı olarak, Oğur ve Bağcı Kılıç'ın (2005) çalışmasında cinsiyet bakımından son-testlerdeki başarı puanları arasında anlamlı bir fark bulunmadığı tespit edilmiştir. Ancak Yazkan'ın (2000) çalışmasında, dramatizasyonun, anlamayı ve hatırlamayı kolaylaştırdığı, dinlediğini anlama davranışının kazandırılmasında okuma yöntemine göre daha etkili olduğu, kız öğrencilerin korkma, heyecanlanma ve sevinç gibi duygusal yaşantıların olduğu metinleri erkek öğrencilere göre daha iyi anladığı sonuçlarına varılmıştır. Aynı şekilde Soytürk'ün (2012) de çalışmasında kızların erkeklere göre örüntüleşmiş hareket becerileri puanları daha yüksek olduğu sonucuna ulaşılmıştır. Söz konusu çalışmalar bu çalışmanın sonucuyla paralellik göstermektedir. Araştırmanın sonuçları ışığında aşağıda yer alan öneriler sunulmuştur.

1. Bu araştırma "Solunum Sistemi" konusu ile sınırlandırılmıştır. Diğer Fen Bilimleri konularında da dramatizasyon tekniğinin akademik başarıya etkisi incelenebilir.

2. Öğrencilere uygulanan ön test ve son testler, öğrencilerin dramatizasyon tekniği etkinlikleri sırasındaki kazanımlarını ölçmede yeterli olmayabilir. Bu nedenle, ön test ve son test uygulaması yerine yine başta ve sonda olmak üzere etkinlik değerlendirmesi (alternatif ölçme ve değerlendirme) yapılabilir.

3. Kontrol ve deney gruplarının son test sonuçları görüldükten sonra dramatizasyon tekniğinin öğrenciler üzerindeki etkisini kanıtlamak için kalıcılık testi gerçekleştirilebilir. 


\section{KAYNAKÇA}

Adıgüzel H. Ö. (2010). Eğitimde Yaratıcı Drama. Ankara 2010.

Becker B. J. \& Hedges L. N. (1984). "Meta-Analysis of Cognitive Gender Differences: A Comment on an Analysis by Rosenthal and Rubin". Journal of Educational Psychology 76 (1984) 583-587.

Bertiz H. (2005). Fen Bilgisi Ögrretmen Adaylarının Yaratıcı Dramaya Yönelik Tutumları ve Öyküleme Çalışmalarına İlişkin Görüşleri. Yüksek Lisans Tezi. Abant İzzet Baysal Üniversitesi, Eğitim Fakültesi, Bolu 2005.

Biegler L. (1998). Implementing Dramatization as an Effective Storytelling Method to Increase Comprehension. Master Thesis. Kean University. Kaynak: http://files.eric.ed.gov/fulltext/ ED417377.pdf. Erişim Tarihi: 15 Mayıs 2015.

Bilek E. (2009). İlköğretim Üçüncü Sinlf Hayat Bilgisi Dersinde Dramatizasyon Yönteminin Öğrencilerin Sosyal-Duygusal Uyumlarına ve Akademik Başarılarına Etkisi. Yüksek Lisans Tezi. Celal Bayar Üniversitesi, Sosyal Bilimler Enstitüsü, Manisa 2009.

Büyüköztürk S. (2007). Sosyal Bilimler İçin Veri Analizi El Kitabı. Ankara 2007.

Christensen L. B. (2004). Experimental Methodology. United States of America 2004.

Çoruh S. (1950). Okullarda Dramatizasyon. İstanbul 1950.

Çakır B. E. (2012). Geleneksel Öğretim Yöntemleri ile Dramatizasyon Yönteminin İlköğretim 2. Sinıf Matematik Dersinde, Öğrencilerin Akademik Başarı ve Kavramların Kalıcllı Düzeylerine Etkisinin Karşılaştırılması. Yüksek Lisans Tezi. Dokuz Eylül Üniversitesi, Eğitim Bilimleri Enstitüsü, İzmir 2012.

Çam F., Özkan E. \& Avinç İ. (2009). "Fen ve Teknoloji Dersinde Drama Yönteminin Akademik Başarı ve Derse Karşı İlgi Açısından Karşılaştırmalı Olarak İncelenmesi: Köy ve Merkez Okulları Örneği”. Gazi Eğitim Fakültesi Dergisi 29/2 (2009) 459-483.

Debre İ. (2008). İlköğretim Sosyal Bilgiler Dersi Coğrafya Konularının Öğretiminde Ders Anlatım Stratejisi Olarak Dramatizasyonun Kullanılmasının Öğrencinin Başarl Düzeyine Etkisi. Yayımlanmamış Yüksek Lisans Tezi. Yeditepe Üniversitesi, Sosyal Bilimler Enstitüsü, İstanbul 2008.

Dirim A. (1998). Yaratıcı Drama. İstanbul 1998.

Dorion K. R. (2009). "Science Through Drama: A Multiple Case Exploration of the Characteristics of Drama Activities Used in Secondary Science Lessons". International Journal of Science Education 31/16 (2009) 2247-2270.

Ediger M. (2001). Student Journal Writing in Science. Kaynak: http://files.eric.ed.gov/fulltext/ ED448462.pdf. Erişim Tarihi: 15 Mayıs 2015.

Ekinözü İ. (2003). İlköğretimde Permütasyon ve Olasıllk Konusunun Dramatizasyon ile Öğretiminin Başarlya Etkisinin İncelenmesi. Yüksek Lisans Tezi. Marmara Üniversitesi, Eğitim Bilimleri Enstitüsü, İstanbul 2003.

Güllü M. (2009). Dramatizasyon Yönteminin Yabancı Dil Öğretimi Üzerindeki Etkisi. Yayımlanmamış Yüksek Lisans Tezi. Beykent Üniversitesi, Sosyal Bilimler Enstitüsü, İstanbul 2009.

Hesapçıŏlu M. (1997). Öğretim Illke ve Yöntemleri. İstanbul 1997.

Kahyaoğlu H., Yavuzer Y. \& Aydede M. N. (2010). "Fen Bilgisi Dersinin Öğretiminde Yaratıcı Drama Yönteminin Akademik Başarıya Etkisi”. Türk Eğitim Bilimleri Dergisi 8/3 (2010) 741-758.

Kaptan F. \& Korkmaz H. (1999). İlköğretimde Etkili Öğretme ve Öğrenme Öğretmen El Kitabı Modül 7. Ankara 1999.

Karacil M. (2009). İlköğretim 1. Kademede Yaratıcı Drama Yönteminin Öğrencinin Akademik Başarısına Etkisi. Yüksek Lisans Tezi. Kafkas Üniversitesi, Sosyal Bilimler Enstitüsü, Kars 2009.

Karasar N. (2005). Bilimsel Araştırma Yöntemi. Ankara 2005.

Kavcar C. $\left(2006^{2}\right)$. Örgün Eğitimde Dramatizasyon. Yaratıcı Drama 1985-1998 Yazılar (Prof. Dr. İnci San'a Armağan). Ed. H. Ömer Adıgüzel. Ankara 2006.

Koç K. (2009). Illkögretim 7. Sinıf Türkçe Dersinde Dramatizasyonla Yaratıcl Dramanın 
Karşılaştırılması. Yayımlanmamış Yüksek Lisans Tezi. Ondokuz Mayıs Üniversitesi, Sosyal Bilimler Enstitüsü, Samsun 2009.

Linnell R. (1982). Approaching Classroom Drama (Teaching Matters). London 1982.

McMillan J. H. \& Schumacher S. (2001). Research in Education. New York 2001.

MEB (2013). Kaynak: http://ttkb.meb.gov.tr/www/guncellenen-ogretim-programlari/icerik/151.

Oğur B. \& Bağcı Kılıç G. (2005). "Fen Bilgisi Derslerine Drama Entegre Edilmesinin Öğrencilerin Fen Başarılarına Etkisi”. Eğitim Araştırmaları 20 (2005) 178-188.

Önder A. (1999). Yasayarak Öğrenme İçin Eğitici Drama. Kuramsal Temellerle Uygulama Teknikleri ve Örnekleri. İstanbul 1999.

Paykoç F. (1987). “Güncel Olaylarla Belirli Gün ve Haftaların Öğretimi”. Ed. B. Özer. Sosyal Bilgiler Öğretimi (1987) 45-56. Eskişehir.

San İ. (1990). "Eğitimde Yaratıcı Drama". Ankara Üniversitesi Eğitim Bilimleri Fakültesi Dergisi 23/2 (1990) 573-582.

San İ. (2001). "Eğitimde Dramanın Kısa Tarihçesi”. Çağdaş Eğitimde Kültür ve Sanat 14 (2001) 81-89.

San İ. (2002). "Yaratıcı Drama-Eğitsel Boyutları". Ed. Ömer H. Adıgüzel. Yaratıcı Drama 1985-1995 Yazılar- (2002) 81. Ankara.

Siddall J. L. (1999). Fifth Graders' Story Dramatizations During Literature Study. Doctoral Thesis. Oak Pak, IL 1999. Kaynak: http://files.eric.ed.gov/fulltext/ED430228.pdf. Erişim Tarihi: 15 Mayıs 2015.

Soytürk M. (2012). 9-11 Yaş Grubu Çocukların Temel Hareket Becerilerinin Örüntüleşmesinde Yaratıcı Dramanın Etkisi. Yüksek Lisans Tezi. Celal Bayar Üniversitesi, Sağlık Bilimleri Enstitüsü, Manisa 2012.

Sengül S. \& Örnek Tükenmez S. (2009). The Effects of Dramatizastion Method on Elementary School Students' Level of Maths Attitudes and Achievements. Procedia Social and Behavioral Sciences 1 (2009) 2131-2135.

Temelli A., Arlı E. E., Biber B. \& Kurt M. (2011). "İnsanlarda Solunum Sistemi Konusunun Kavram Haritalarıyla Öğretilmesinin Öğrencilerin Akademik Başarısına Etkisi”. Iğdır Üniversitesi Fen Bilimleri Enstitüsü Dergisi 1/2 (2011) 61-66.

Türk Dil Kurumu. (2004). Türkçe Sözlük. Ankara 2004.

Ünüvar T. (2007). İlkögrretim 6. Sinıf Fen ve Teknoloji Dersi Programında Yer Alan Canlının İ̧ Yapısına Yolculuk Ünitesinde Yaratıcı Drama ile Öğretimin Öğrencilerin Erişişine Etkisi. Yüksek Lisans Tezi. Selçuk Üniversitesi, Fen Bilimleri Enstitüsü, Konya 2007.

Yağmur E. (2010). 7. Sinıf Fen ve Teknoloji Dersinin Yaratıcı Dramam Destekli İ̧slenmesinin Eleştirel Düşünme Becerisi ve Başarı Üzerine Etkisi. Yüksek Lisans Tezi. Sakarya Üniversitesi, Fen Bilimleri Enstitüsü, Sakarya 2010.

Yalçın K. \& Karakaş S. (2008). “Çocuklarda Bilgi İşlemedeki Üst İşlemlerin Yaşa Bağlı Değişimi”. Türk Psikiyatri Dergisi 19/3 (2008) 257-265.

Yazkan M. (2000). Illköğretim Okullarının I. Kademesinde Dinlediğini Anlama Davranışının Kazandırılmasına Dramatizasyonun Etkisi. Yayımlanmış Yüksek Lisans Tezi. Marmara Üniversitesi, Eğitim Bilimleri Enstitüsü, İstanbul 2000.

Yücel Toy B. (2015). “Öğretmen Eğitiminde Dramatizasyon: Öğrenme Kuramlarının Öğretimi Üzerine Bir Çalışma”. Uluslararası Ĕgitim Programları ve Öğretim Çalışmaları Dergisi 5/9 (2015) 49-62. 